\title{
Impact of castor meal on root-knot and free-living nematodes
}

\author{
Cecilia Helena Silvino Prata Ritzinger ${ }^{*}$, Paul De Ley², Antoon Teunis Ploeg², Robert McSorley³, Irma Tandingan De Ley²
}

${ }^{1}$ Embrapa Cassava \& Fruits, R. Embrapa s/n, C.P. 00744380-000 - Cruz das Almas, BA - Brazil.

2University of California Riverside - Dept. of Nematology, Riverside CA 92521 - USA.

3University of Florida - Dept. of Nematology, Gainesville FL 32611 - USA.

*Corresponding author <cecilia.ritzinger@embrapa.br>

Edited by: Cláudio Marcelo Gonçalves de Oliveira
ABSTRACT: Soil amendment may enhance soil quality as well as reduce plant-parasitic nematode. Despite the many applications already undertaken using castor meal, its efficiency in controlling root-knot nematodes (RKN, Meloidogyne incognita) when applied to melon (Cucumis melo) is still not clear. Three different amounts of castor meal (Ricinus communis) applied were evaluated in microplots planted with melon either with or without RKN. The impact of castor meal on soil free-living nematode communities was also determined. Total nematode genera richness was estimated as 37 for the entire set of microplots sampled across both sampling dates. Rarefaction analysis resulted in 12 collector's curves out of the total of 30 that reached the horizontal asymptote. Univariate ANOVA with two factors yielded differences $(p \leq 0.05)$ only with regard to the time factor. Simpson, Shannon, Evenness and Equitability indices showed a trend toward moderate increases by the end of the experiment, while the other indices were higher for tomato in pre-transplant sampling compared to harvest. Nematode community and diversity changed during the course of the experiment, although there was substantial confounding heterogeneity within and between the factorial combinations from the beginning. Root knot population was not reduced by the castor meal but increased throughout the period, regardless of treatment. RKN reduced melon yield, number and weight of melon.

Keywords: Bray-Curtis similarity measure, nematode community, trophic group, univariate, multivariate analyses
Received August 20, 2013

Accepted February 21, 2014 ily, soil ecosystem evaluation is often confined to these parameters. Nematode community indices are especially useful in detecting impacts of various soil treatments on nematode communities and soil quality (Bongers, 1999; Sochová et al., 2005; McSorley, 2011; Bastow, 2012). However, calculating these indices requires specialist taxonomical knowledge and is labor intensive, which makes it impracticable for routine analysis.

Ecological studies on nematode community associated with $C$. melo showed that Dorylaimida and Aphelenchida were under moderate spatial dependence, while Rotylenchulus reniformis expressed strong dependence in areas with nematode symptoms (Torres et al., 2006).

In this study, micro-plots infested with different population densities of $M$. incognita were used to determine the effects of a castor meal soil amendment on the overall nematode community structure of a melon crop.

\section{Materials and Methods}

The experiment was carried out in micro-plots in Riverside, California, USA (+33 $57^{\circ} 41.5038^{\prime \prime},+117^{\circ}$ $20^{\prime} 7.9002^{\prime \prime)}$, consisting of a $1 \mathrm{~m}$ diameter concrete tube embedded vertically $1 \mathrm{~m}$ deep $\left(0.8 \mathrm{~m}^{-3}\right)$ into the soil, containing a sandy soil $\left(\mathrm{N}=230 \mathrm{mg} \mathrm{dm}^{-3}, \mathrm{P}=19 \mathrm{mg} \mathrm{dm}^{-3}\right.$, $\mathrm{K}=59 \mathrm{mg} \mathrm{dm}^{-3}, \mathrm{Mg}=132 \mathrm{mg} \mathrm{dm}^{-3}, \mathrm{OM}=5 \mathrm{~g} \mathrm{dm}^{-3}$, $\mathrm{pH}$ in water $=7.1$ ). The microplots had been previously infested with $M$. incognita and had been used in a rotation trial with tomato (Solanum lycopersicon), marigold (Tagetes patula) and fodder radish (Raphanus sativus). For the two years preceding this experiment, the microplots had been left fallow. Before starting the trial, weeds 
were removed and two tomato 'Peto98' seedlings were transplanted into each microplot on 27 May 2011 and grown for five weeks to increase resident $M$. incognita population.

After removal of the tomatoes, a trial with a $2 \times$ 3 factorial design and five replicates was started. There were two initial $M$. incognita nematode levels (low "_" and high " +") and three castor meal mulch rates $(0,40$, and $80 \mathrm{~g}$ per micro-plot).

Two four-week-old melon seedlings were planted in each micro-plot on 01 July 2011. Three weeks later, one melon plant was dug up from each microplot and examined for presence and severity of root-galling. Castor meal was applied around the base of each melon plant on July $27^{\text {th }}$ and on Aug $28^{\text {th }}$. The experiment was harvested 13 weeks after planting, on 28 September, when the number and the length of primary branches, and fruit number and weight were recorded. The roots were examined for root-galling and the severity of galling was scored on a scale from 0 to 10 (0: no galling, 10: $100 \%$ of root system galled; Bridge and Page, 1980).

Soil samples for nematode analysis were collected from each micro-plot at the time of melon planting (Pi) and at harvest. Nematodes were extracted from samples using two extraction methods. Two $100 \mathrm{~cm}^{-3}$ sub-samples were taken from each soil sample for nematode extraction. One of the sub-samples was placed on a Baermann funnel (Hooper, 1990) for five days, and used to determine levels of actively moving soil nematodes. The other sub-sample was used in the sugar flotation method (Jenkins, 1964) which also yields inactive stages of soil nematodes. The total number of free-living nematodes as well as the number of second-stage $M$. incognita juveniles (J2) per $100 \mathrm{~cm}^{-3}$ soil was determined. A greenhouse bioassay was done to verify initial $M$. incognita soil counts from the micro-plots: A soil subsample (200 g) from each micro-plot was placed in a plastic tube, and seeded with a melon (cantaloupe 'Durango'). Three weeks after seedling emergence, plants were washed from the tubes, and the roots were examined for the presence of root galls (Bridge and Page, 1980), indicating the presence of RKN.

Thirty micro-plots were selected for the trial, 15 being rated as low "-" and 15 as high " + "RKN, based on the bioassay results described above. At harvest nematode densities (Pf) were determined from soil samples collected from the 30 micro-plots by collecting eight cores from each microplot using a $2.5 \mathrm{~cm} \times 30 \mathrm{~cm}$ hand auger; the samples were combined for extraction following the same procedure as described above.

Castor meal is a product with high protein content. On average it has $43 \%$ crude protein and $20 \%$ fiber. It typically contains nitrogen, phosphorus, potassium, calcium, and magnesium, but the chemical composition varies between batches and sources (Severino et al., 2012). The castor meal used in this study was obtained from the Hale cultivar, with seeds submitted to dry heating in an oven at $105{ }^{\circ} \mathrm{C}$ for $3 \mathrm{~h}$, followed by expeller extraction with additional heat in the expeller body. The castor meal was not subjected to oil extraction with solvent.

After nematode extraction and counting as described above, up to 100 nematodes were randomly picked and fixed in $4 \%$ formalin: $1 \%$ glycerin solution, transferred to pure glycerin by the Seinhorst method (Orajay, 2005), and mounted on permanent slides for genus identification. Where there were fewer than 100 nematodes in a sample, all nematodes were mounted.

Nematodes were identified to genus using a compound microscope at 400-1200x magnification with the appropriate keys and monographs for the taxa in question (Jairajpuri and Ahmad, 1992; Siddiqi, 2001; Eyualem et al., 2006; Holovachov et al., 2010). Individual variation in specimens of Acrobeloides and Cephalobus prevented us from clearly distinguishing between the two genera in a consistent manner (see Holovachov et al., 2010). In the absence of taxonomic clarity regarding their differentiating characters, individuals resembling either genus were pooled as one and the same genus for our purposes. In cases where adult morphology was needed for identification but no corresponding adults were found in the samples, juveniles were identified at family or suborder level only. For counting, individual identifications were data-based in File Maker Pro v6 (Filemaker Inc., Santa Clara, US) and exported for automatic conversion to genus counts per replicate using an AppleScript droplet custom.

Plant parameters were submitted to analysis of variance using the GLM procedure in SAS (SAS Institute Inc, Cary, NC, USA), and nematode community structure with non-metric MDS and all nine diversity indices available in PAST v2.17 (Bing et al., 2013); see reviews in Neher and Darby, 2009; Maurer and McGill, 2010; Merganič et al., 2012) followed by two-way ANOVA of all respective pairs of the three experimental factors: sampling date (Pi and $\mathrm{Pf}$ ), initial RKN population level $(+$ and -1 and castor meal rate $(0,40$ or 80 g per plant) to detect the presence of differences between treatments for individual factors and interactions between two factors. In order to assess the contribution of the bacterivorous nematode diversity to the overall nematode diversity, the same nine diversity indices were calculated based only on bacterivore abundances per genus, and then subjected in the same manner to two-way ANOVA of all pairs of the same three experimental factors. We also used PAST to calculate individual rarefaction or collector's curves (Simberloff, 1978) for the number of all nematode genera in each replicate from each treatment, to obtain estimates of total genus richness.

Normality tests as implemented in PAST were applied to replicates per treatment, and failed in the large majority of cases to provide unambiguous support for normal distribution. We therefore applied a non-parametric method of multivariate analysis by non-metric MultiDimensional Scaling (nMDS, see Neherand Darby, 2009), as well as non-parametric representation of data plots through box-and-whisker plots rather than confi- 
dence intervals. The nMDS function in PAST was applied using Bray-Curtis similarity measures to plot all individual replicates of all treatments as median, range and quartiles for each treatment, and for nematode proportional abundances per genus as based on our identifications of 100 randomly picked nematodes from each replicate. Both datasets were also transposed to plot nematode genera by their occurrence in the individual replicates and averaged per treatment, respectively.

\section{Results}

Individual replicates yielded from four to 13 nematode genera, while genus counts per treatment ranged between 11 and 22. Total genus richness equaled an estimate of 37 for the entire set of sampled microplots across both sampling dates (Table 1). Four taxa were represented by juveniles that could be identified by family or suborder only. Rarefaction analysis, which is a technique to assess species richness from the results of sampling, resulted in 12 collector's curves out of the total of 30 that reached the horizontal asymptote, or were shaped with sufficient curvature to suggest an asymptote would be reached if more nematodes had been identified from the relevant sample. The other 18 curves did not reach an asymptote but instead, matched or closely approximated an inclined straight line for most of their course (data not shown).

Univariate analyses with two-factor ANOVA (Table 2) of diversity indices calculated from all nematodes genus abundances yielded differences only for the time factor and this with the Menhinick, Margalef, Fisher alpha and Berger-Parker indices. The first three indices mostly produced significances greater than $99 \%$ and the latter significances greater than $95 \%$. Simpson, Shannon, Evenness and Equitability indices showed a non-signifi- cant trend towards moderate increases by the end of the experiment, while the other indices were more clearly lower at harvest compared to pre-transplant. Univariate analyses with two-way ANOVA of the same indices calculated only from bacterivore genus abundances also yielded significant differences as regards time factor, in this case as measured by the Simpson, Evenness, Margalef, Equitability and Berger-Parker indices (data not shown). Additionally, univariate analyses of bacterivore diversity only yielded significant interactions between time and initial RKN population level for the Simpson, Shannon, Brillouin and Berger-Parker indices.

Multivariate analyses with nMDS show a similarity $(p \leq 0.01)$ between the sample series collected just before planting and the samples collected when melon plants were harvested after three months (Figure 1). Sep-

Table 1 - Nematode genera by trophic group after melon harvest.

\begin{tabular}{lll}
\hline Bacterivores & $\begin{array}{c}\text { Plant parasites and } \\
\text { Fungivores }\end{array}$ & \multicolumn{1}{c}{ Omnivores } \\
\hline $\begin{array}{l}\text { Achromadora } \\
\text { Acrobeles }\end{array}$ & & \\
Acrobeloides+Cephalobus & & \\
Cervidellus & & \\
Diploscapter & Aphelenchoides & Allodorylaimus \\
Drilocephalobus & Aphelenchus & Aphidorylaimus \\
Eucephalobus & Ditylenchus & Discolaimellus \\
Mesorhabditis & Meloidogyne & Dorylaimina \\
Monhystrella & Tylenchidae & Dorylaimellus \\
Panagrolaimus & Tylenchus & Dorylaimus \\
Plectus & Tylencholaimus & Ecumenicus \\
Prismatolaimus & Tylencholaimidae & Enchodelus \\
Prodesmodora & Tylenchorhynchus & Microdorylaimus \\
Rhabditidae & & \\
Rhabdolaimus & & \\
Stegelletina & & \\
Tricephalobus & & \\
Zeldia & & \\
\hline
\end{tabular}

Table 2 - Diversity indices for each combination of date $\mathrm{x}$ root knot nematode (RKN) second stage juvenile (J2) high or low level x castor amount, averaged from five replicates each (number of genera is not average but total for that combination's set of five replicates).

\begin{tabular}{|c|c|c|c|c|c|c|c|c|c|c|c|c|}
\hline \multirow{3}{*}{$\begin{array}{l}\text { Sampling Date } \\
\text { RKN second stage juvenile (J2) population level } \\
\text { Castor amendment }\end{array}$} & \multicolumn{6}{|c|}{$\begin{array}{c}25 \text { June } 2011 \\
\text { (pre-transplanting) }\end{array}$} & \multicolumn{6}{|c|}{$\begin{array}{c}28 \text { Sept } 2011 \\
\text { (harvest) }\end{array}$} \\
\hline & & $\begin{array}{c}\text { Low } \\
(-)\end{array}$ & & & $\begin{array}{c}\text { High } \\
(+)\end{array}$ & & & $\begin{array}{c}\text { Low } \\
(-)\end{array}$ & & & $\begin{array}{c}\text { High } \\
(+)\end{array}$ & \\
\hline & 0 & 40 & 80 & 0 & 40 & 80 & 0 & 40 & 80 & 0 & 40 & 80 \\
\hline Number of genera & 16 & 13 & 17 & 20 & 15 & 22 & 13 & 18 & 12 & 11 & 14 & 12 \\
\hline Number of individuals randomly picked \& identified & 63 & 60 & 90 & 88 & 70 & 83 & 99 & 101 & 92 & 102 & 104 & 104 \\
\hline Dominance & 0.41 & 0.32 & 0.42 & 0.40 & 0.33 & 0.38 & 0.36 & 0.18 & 0.17 & 0.32 & 0.27 & 0.26 \\
\hline Simpson (=1-Dominance) & 0.59 & 0.68 & 0.58 & 0.60 & 0.67 & 0.62 & 0.64 & 0.82 & 0.82 & 0.68 & 0.73 & 0.74 \\
\hline Shannon & 1.48 & 1.65 & 1.46 & 1.56 & 1.70 & 1.64 & 1.39 & 1.95 & 1.93 & 1.39 & 1.55 & 1.69 \\
\hline Evenness & 0.27 & 0.40 & 0.25 & 0.24 & 0.36 & 0.23 & 0.31 & 0.39 & 0.57 & 0.36 & 0.34 & 0.45 \\
\hline Brillouin & 1.25 & 1.42 & 1.27 & 1.35 & 1.46 & 1.40 & 1.26 & 1.77 & 1.76 & 1.27 & 1.41 & 1.54 \\
\hline Menhinick & 2.01 & 1.68 & 1.79 & 2.13 & 1.79 & 2.41 & 1.31 & 1.79 & 1.25 & 1.09 & 1.37 & 1.18 \\
\hline Margalef & 3.62 & 2.93 & 3.55 & 4.25 & 3.29 & 4.75 & 2.61 & 3.68 & 2.43 & 2.16 & 2.80 & 2.37 \\
\hline Equitability & 0.53 & 0.64 & 0.55 & 0.52 & 0.63 & 0.53 & 0.54 & 0.67 & 0.78 & 0.58 & 0.59 & 0.68 \\
\hline Fisher alpha & 6.90 & 5.11 & 6.19 & 8.09 & 5.86 & 9.78 & 4.01 & 6.36 & 3.69 & 3.13 & 4.35 & 3.50 \\
\hline Berger-Parker & 0.62 & 0.53 & 0.63 & 0.61 & 0.55 & 0.59 & 0.55 & 0.23 & 0.30 & 0.43 & 0.37 & 0.42 \\
\hline
\end{tabular}


arate plotting of individual replicates did not produce clearly segregated clusters per factorial combination and was therefore difficult to interpret visually. Plotting of medians with box-and-whisker plots for both axes indicated that initial differences among nematode communities were of a similar order of magnitude as differences between these from the end of the experiment. Nevertheless, some trends were apparent in that eigenvectors of various measurements of fruits and plants indicate combination without castor amendment and with low initial levels of RKN moved most of all in the direction of vectors corresponding to smaller fruit sizes and more rotten fruits (data not shown). The other combinations moved to positions corresponding to larger fruit size and weight as well as better plant growth, with three combinations tracking averaged total counts of J2 RKN more closely $180 \mathrm{~g}$ castor $\times$ absence of RKN, $0 \mathrm{~g}$ castor $\times$ pres- ence of RKN and $80 \mathrm{~g}$ castor $\times$ high RKN level) while both combinations with $40 \mathrm{~g}$ castor tracked total counts of free-living nematodes more closely.

There was no interaction between amendment and the $M$. incognita level at the start of the trial (Table 3). Application of castor residue did not affect the number or length of melon branches or the fruit number or weight. However, the length of the branches, and the number and weight of the harvested fruits were reduced $(p \leq 0.05)$ when $M$. incognita was present at the start of the trial.

\section{Discussion}

Nematode community and diversity changed during the course of the experiment, although there was plenty of confounding heterogeneity within and be-

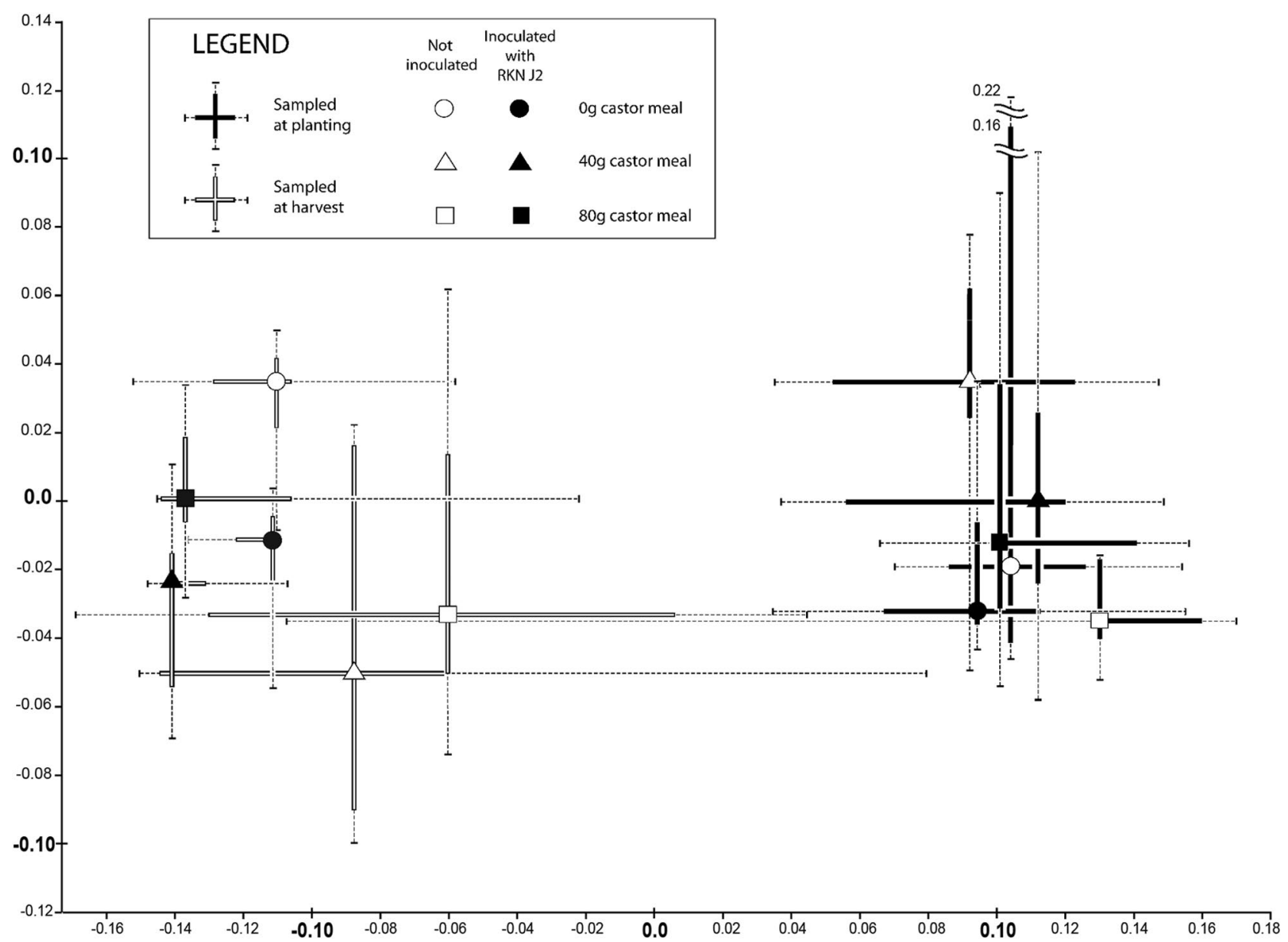

Figure 1 - Non-parametric multidimensional scaling graph representing the two axes with greatest separation between treatments and time points, based on abundances of all nematode genera encountered. Medians of five replicates per treatment/time combination are shown as circles, triangles and squares, representing micro-plots with addition of 0,40 or $80 \mathrm{~g}$ castor meal, respectively. Filled circles, triangles and squares represent micro-plots inoculated with Meloidogyne second stage juveniles. Minimum, lower quartile, upper quartile and maximum values are shown for both axes as box-and-whisker plots extending from each median. Solid bars represent treatments at planting of melon seedlings, while open bars represent treatments at harvest three months later. 
Table 3 - Effect of amendment treatments on root-knot nematode (Meloidogyne incognita) levels per $100 \mathrm{~cm}^{-3}$ soil and plant parameters of a susceptible melon cantaloupe 'Durango', Riverside, CA, 2011.

\begin{tabular}{|c|c|c|c|c|}
\hline Castor meal levels & $\begin{array}{l}\text { Branch } \\
\text { length }\end{array}$ & $\begin{array}{c}\text { Number of } \\
\text { branch }\end{array}$ & $\begin{array}{c}\text { Number of } \\
\text { fruit }\end{array}$ & $\begin{array}{c}\text { Fruit } \\
\text { weigh }\end{array}$ \\
\hline & $\mathrm{cm}$ & & & $\mathrm{kg}$ \\
\hline \multicolumn{5}{|c|}{ No root-knot second stage juvenile (J2) found at start of trial } \\
\hline $0 \mathrm{~g}$ & 90.00 & 4.0 & 2.0 & 1.70 \\
\hline $40 \mathrm{~g}$ & 98.00 & 2.8 & 2.0 & 2.07 \\
\hline $80 \mathrm{~g}$ & 72.00 & 4.2 & 2.4 & 2.61 \\
\hline ×Mean & 87.00 & $3.7 \mathrm{~A}$ & $2.1 \mathrm{~A}$ & $2.12 \mathrm{~A}$ \\
\hline \multicolumn{5}{|c|}{ Root-knot second stage juvenile $(\mathrm{J} 2$ ) found at start of trial } \\
\hline $0 \mathrm{~g}$ & 40.80 & 4.0 & 0.6 & 0.37 \\
\hline $40 \mathrm{~g}$ & 58.0 & 3.4 & 0.8 & 0.77 \\
\hline $80 \mathrm{~g}$ & 51.0 & 3.2 & 0.2 & 0.09 \\
\hline Mean & $50.00 \mathrm{~B}$ & $3.5 \mathrm{~A}$ & $0.5 \mathrm{~B}$ & $0.41 \mathrm{~B}$ \\
\hline \multicolumn{5}{|c|}{ Root-knot second stage juvenile ( $\mathrm{J} 2$ ) found at start of trial (present/absent) } \\
\hline $\mathrm{F}$ & 15.97 & 0.12 & 28.80 & 22.19 \\
\hline $\mathrm{P}$ & 0.0005 & 0.7364 & 0.0001 & 0.0001 \\
\hline \multicolumn{5}{|c|}{ Castor meal level } \\
\hline & 1.17 & 1.83 & 0.05 & 0.47 \\
\hline & 0.3265 & 0.1827 & 0.9513 & 0.6329 \\
\hline \multicolumn{5}{|c|}{ Nematode level $\times$ Castor meal level } \\
\hline & 0.82 & 1.42 & 1.05 & 1.26 \\
\hline & 0.45 & 0.2612 & 0.3655 & 0.3009 \\
\hline
\end{tabular}

xMeans in columns followed by the same letter do not differ $(p \leq 0.05)$ according to statistical test performed on the corresponding parameter.

tween the factorial combinations from the start. With the majority of rarefaction curves not attaining (nor trending towards attaining) a horizontal plateau, many of the individual micro-plots harbored nematode communities that were not homogenous within each $1 \mathrm{~m}$ diameter soil volume. Perhaps nematode diversity was still changing due to the after-effects of previous use of the micro-plot before the experiment was established, or different patterns of vertical dispersal and introduction occurred in each micro-plot /via aboveground mechanisms as well as from and to soils below sampling depth), or the entire field did not represent a truly homogeneous set of conditions to begin with. Most likely, a combination of all the foregoing factors contributed to complicate exact estimations of numbers of taxa in each micro-plot.

It is difficult to interpret the results regarding other variables because they may not represent the nematode diversity very satisfactorily. Possibly, the period of time was not long enough to recover all nematodes.

Changes corresponded mostly to low productivity and fruit damage in the combination of detected $(+)$
RKN versus no application of castor residues. One explanation for this could be that the soil was so poor in organic matter that even modest amounts of castor meal helped to boost fruit growth by adding organic matter and nutrients, resulting in more vigorous root growth. The presence of larger and healthier root systems may also have led to an increase in RKN numbers resulting in higher levels of RKN parasitism correlated with higher melon productivity.

Number and weight of melon fruits were higher when no root-knot nematodes were found at the start of the trial, but the castor meal amendment did not affect melon yields, whether $M$. incognita was present or not. This confirms that use of organic amendment to manage nematodes is unpredictable because it depends on many factors as highlighted by McSorley (2011); Oka (2010); and Bastow (2012).

There are many situations where organic amendment did not affect plant-parasitic nematodes (McSorley, 2011), but the fact that in our experiment the amendment did not affect plant growth was unexpected. Micro-plots had been fallow before the trial started and would not have much residual N. Therefore, we expected the plants to respond to the nutrient input in the form of castor meal. For melon, the level of nitrogen has more influence on the growth and yield than any other single plant nutrient (Hartz et al., 2008).

As discussed by McSorley (2011), while amendments may improve plant growth and stimulate the soil food web, additional studies and testing are needed. The inconsistent effects of soil amendments with regard to nematode suppression may be due to the different mechanisms involved in this suppression (Oka, 2010). The time necessary to generate and subsequently release nematicidal compounds may be affected by the period the amendment persists in the soil. Therefore, this threemonth experiment may not have been long enough for the amendment to reach its full effect on the free-living nematodes over the plant-parasitic nematode $M$. incognita which was dependent on the melon root system. According to Oka (2010), the increase in free-living nematodes may also enhance antagonistic organisms to become established and proliferate.

Our results are in accordance with Torres et al. (2006) who showed that low values of nematode community indices and low population levels of omnivores and predators suggested that the fallow period was not sufficient to re-establish balance in the nematode community. As k-strategist, omnivorus nematodes are typically slow to recover from disturbance and recolonize (Bongers, 1999 Ferris et al., 2001). Among the total genus richness for the entire set of sampled micro-plots, 18 genera belonged to the bacterivores trophic group, thereby suggesting this group as an important source of diversity, contributing to the observed changes in overall nematode diversity. This possibility is supported by the fact that our statistical analyses detected changes in di- 
versity with time, both for overall nematode community and for the bacterivores trophic group only. This result is in accordance with Ferris et al. (2001) and Bastow (2012) who found that bacterivores typically respond most quickly to the addition of $\mathrm{N}$. In our study the high rate of castor meal amendment, which has a high $\mathrm{N}$ content 18 $\%)$, presumably also favor the bacterivores community or trophic group. Nevertheless, we found no significant differences in diversity when different levels of castor meal were applied, neither in the overall nematode community nor in the bacterivores trophic group alone. A possible explanation for this lack of effect could be that under our particular experimental conditions, nematode diversity (including bacterivore diversity) was primarily affected by factors common to all micro-plots, such as seasonal temperature changes, root growth and irrigation.

\section{Conclusion}

Root knot was not affected by the rate of castor meal but the population increased after time in all treatments. Diversity of free living nematodes was unaffected by the applied rate of castor meal. The bacteriovore trophic group was the major component of the nematode community in this melon cultivation system.

\section{Acknowledgements}

To Dr. Ana Lucia Borges (Embrapa), for interpreting the chemical analysis of the castor meal as well as the soil analyses and nutrient needs of melon crop. We are also grateful to Edward Scott (University of Riverside, CA), for the logistical support with micro-plot and greenhouse study.

\section{References}

Bastow, J.L. 2012. Resource quality in a soil food web. Biology and Fertility of Soils 48: 501-510.

Bing, H.; Harper, D.A.T.; Hammer, Ø. 2013. Introduction to PAST: a comprehensive statistics software package for paleontological data analysis. Acta Palaeontologica Sinica 52: 161-181.

Bongers, T. 1999. The maturity index, the evolution of nematode life history traits, adaptive radiation and cp-scaling. Plant and Soil 212: 13-22.

Bridge, J.; Page, S.L.J. 1980. Estimation of root-knot nematode infestation levels on roots using a rating chart. Tropical Pest Management 26: 296-298.

Eyualem, A.; Traunspurger, W.; Andrassy, I. 2006. Freshwater Nematodes: Ecology and Taxonomy. CABI, Wallingford, UK.

Ferris, H.; Bongers, T.; Goede, R.G.M.de. 2001. A framework for soil food web diagnostics: extension of the nematode faunal analysis concept. Applied Soil Ecology 18: 113-29.

Ferris, H.; Sanchez-Moreno, S.; Brennan, EB. 2012. Structure, functions and interguild relationships of the soil nematode assemblage in organic vegetable production. Applied Soil Ecology 61: 16-25.
Hartz, T.; Cantwell, M.; Mickler, J.; Mueller, S.; Stoddard, S.; Turine, T. 2008. Cantaloupe Production in California. University of California, Davis, CA, USA. (Vegetable Production Series, 7218). Available at: http://anrcatalog.ucdavis.edu/pdf/7218.pdf [Accessed Mar 22, 2013]

Holovachov, O.; Tandingan De Ley, I.; Mundo-Ocampo, M.; De Ley, P. 2010. Identification of Cephaloboidea (Nematoda). University of California, Riverside, CA, USA.

Hooper, D.J. 1990. Extraction and processing of plant and soil nematodes. p. 45-68. In: Luc, M.; Sikora, R.A.; Bridge, J., eds. Plant-parasitic nematodes in subtropical and tropical Agriculture. CAB International, Wallinford, UK.

Ingham, R.E.; Trofymov, J.A.; Ingham, E.R.; Coleman, D.C. 1985. Interaction of bacteria, fungi, and their nematode grazers: effects on nutrient cycling and plant growth. Ecological Monographs 55: 119-140.

Jairajpuri, M.S.; Ahmad, W. 1992. Dorylaimida: Free-Living, Predaceous and Plant-Parasitic Nematodes. Brill, Leiden, The Netherlands.

Jenkins, W.R. 1964. A rapid centrifugal flotation technique for separating nematodes from soil. Plant Disease Reporter 48: 692.

Maurer, B.A.; McGill, B.J. 2010. Measuring Species Diversity. p. 55-65. In: Magurran, A.E.; McGill, B.J., eds. Biological diversity: frontiers in measurement and assessment. Oxford University Press, Oxford, UK.

McSorley, R.; Gallaher, R.N. 1995. Cultural practices improve crop tolerance to nematodes. Nematropica 25: 53-60.

McSorley, R. 2011. Overview of organic amendments for management of plant-parasitic nematodes, with case studies from Florida. Journal of Nematology 43: 69-81.

Merganič, J.; Merganičevá, K.; Marušák, R.; Auolenská, V. 2012. Plant diversity of forests. p. 3-28. In: Blanco, J.A.; Lo, Y.H., eds. Forest ecosystems: more than just trees. InTech, Rijeka. Available at: http://www.intechopen.com/books/forestecosystems-more-than-just-trees [Accessed Mar 22, 2013]

Neher, D.A.; Darby, B.J. 2009. General community indices that can be used for anlaysis of nematode assemblages. p. 107123. In: Wilson, M.; Kakouli-Duarte, T., eds. Nematodes as environmental bioindicators. CABI, Wallingford, UK.

Oka, Y. 2010. Mechanisms of nematode suppression by organic soil amendments: a review. Applied Soil Ecology 44: 101-115.

Orajay, J.I. 2005. Processing, mounting and identification of nematodes. p. 47-49. In: Dela Cruz, F.S.; Bergh, I. van den; Waele, D.; Hautea, D.M.; Molina, A.B., eds. Towards management of Musa nematodes in Asia and the Pacific: technical manual. Available at: http://www.bioversityinternational.org/uploads/ tx_news/Towards_management_of_Musa_nematodes_in_Asia_ and_the_Pacific_-_Technical_manual_1099.pdf [Accessed Mar 22, 2013]

Pacini, C.; Wossink, A.; Giesen, G.; Vazzana, C.; Huirne, R. 2003. Evaluation of sustainability of organic, integrated and conventional farming systems: a farm and field scale analysis. Agriculture, Ecosystems and Environment 95: 273-288.

Ritzinger, C.H.S.P.; McSorley, R.; Gallaher, R.N. 1998. Effect of Meloidogyne arenaria and mulch type on okra in microplot experiments. Supplement to Journal of Nematology 30: 616623. 
Ritzinger, C.H.S.P.; McSorley, R. 1998. Effect of castor and velvetbean organic amendments on Meloidogyne arenaria in greenhouse experiments. Supplement to Journal of Nematology 30: 624-631.

Severino, L.S.; Auld, D.L.; Baldanzi, M.; Cândido, M.J.D.; Chen, G.; Crosby, W.; Tan, D.; He, X.; Lakshmamma, P.; Lavanya, C.; Machado, O.L.T.; Mielke, T.; Milani, M.; Miller, T.D.; Morris, J.B.; Morse, S.A.; Navas, A.A.; Soares, D.J.; Sofiatti, V.; Wang, M.L.; Zanotto, M.D.; Zieler, H. 2012. A review on the challenges for increased production of castor. Agronomy Journal 104: 853-880.

Siddiqi, M.R. 2001. Tylenchida: parasites of plants and insects. 2ed. CABI, Wallingford, UK.

Simberloff, D.S. 1978. Use of rarefaction and related methods in ecology. p. 150-165. In: Dickson, K.L.; Cairns Jr., J.; Livingston, R.J., eds. Biological data in water pollution assessment: quantitative and statistical analyses. American Society for Testing and Materials, Philadelphia, PA, USA.
Sochová, I.; Hofman, J.; Holoubek, I. 2005. Using nematodes in soil ecotoxicology. Environment International 32: 374-383.

Stirling, G.R. 1991. Biological Control of Plant-Parasitic Nematodes: Progress, Problems and Prospects. CABI, Wallingford, UK.

Torres, G.R.C.; Pedrosa, E.M.R.; Montenegro, A.A.A.; Michereff, S.J.; Moura, R.M. 2006. Ecological aspects of nematode community associated with Cucumis melo crop in Rio Grande do Norte, Brazil. Nematologia Brasileira 30: 1-9 (in Portuguese, with abstract in English). 